
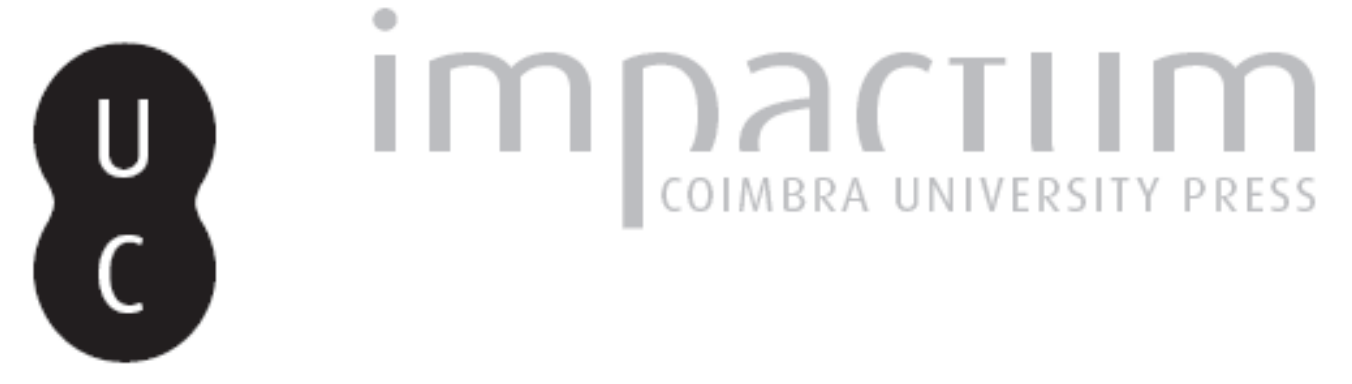

\title{
Espaços alternativos na internet como formas de visibilizar as mulheres no jornalismo brasileiro
}

Autor(es): $\quad$ Vecchio-Lima, Myrian Del; Souza, Humberto da Cunha Alves de

Publicado por: Imprensa da Universidade de Coimbra

URL persistente:

URI:http://hdl.handle.net/10316.2/43231

DOI:

DOI:https://doi.org/10.14195/2183-5462_31_9

Accessed : $\quad$ 26-Apr-2023 15:05:13

A navegação consulta e descarregamento dos títulos inseridos nas Bibliotecas Digitais UC Digitalis, UC Pombalina e UC Impactum, pressupõem a aceitação plena e sem reservas dos Termos e Condições de Uso destas Bibliotecas Digitais, disponíveis em https://digitalis.uc.pt/pt-pt/termos.

Conforme exposto nos referidos Termos e Condições de Uso, o descarregamento de títulos de acesso restrito requer uma licença válida de autorização devendo o utilizador aceder ao(s) documento(s) a partir de um endereço de IP da instituição detentora da supramencionada licença.

Ao utilizador é apenas permitido o descarregamento para uso pessoal, pelo que o emprego do(s) título(s) descarregado(s) para outro fim, designadamente comercial, carece de autorização do respetivo autor ou editor da obra.

Na medida em que todas as obras da UC Digitalis se encontram protegidas pelo Código do Direito de Autor e Direitos Conexos e demais legislação aplicável, toda a cópia, parcial ou total, deste documento, nos casos em que é legalmente admitida, deverá conter ou fazer-se acompanhar por este aviso.

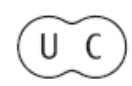




\section{Media Jornalismo}

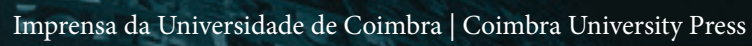

N. 31 Vol. 17, N. ${ }^{\circ} 2$ - 2017

Esia

(2) M MEDIA E DIVERSIDADE

लिखिएक

2)

*).

() (6) $3(9)$

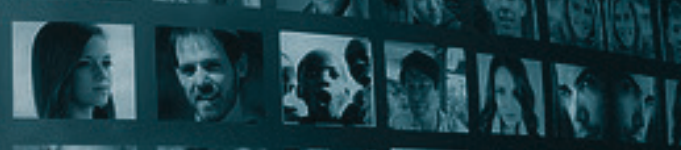

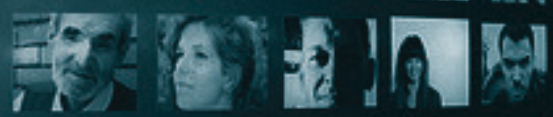

* a

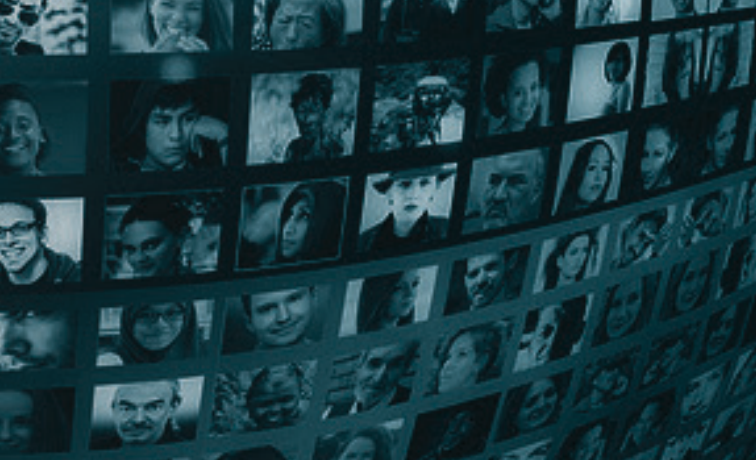

तथ 


\title{
ESPAÇOS ALTERNATIVOS NA INTERNET COMO FORMAS DE VISIBILIZAR AS MULHERES NO JORNALISMO BRASILEIRO
}

\section{ALTERNATIVE SPACES ON THE INTERNET AS A MEAN TO MAKE WOMEN VISIBLE IN BRAZILIAN JOURNALISM}

\author{
MYRIAN DEL VECCHIO-LIMA \\ Universidade Federal do Paraná (UFPR), 1299 - Centro, Curitiba - PR, 80060-000, Brasil \\ Université Lyon Lumière 2, 69007 Lyon, França \\ myriandel@gmail.com
}

HUMBERTO DA CUNHA ALVES DE SOUZA

Universidade Federal do Paraná (UFPR), 1299 - Centro, Curitiba - PR, 80060-000, Brasil

hu.souza@gmail.com

\begin{abstract}
Resumo
Apesar da feminização das redações jornalísticas latino-americanas, o Global Report on the Status of Women in the News Media (2015) aponta que 0 estatuto profissional superior nestes espaços é ainda masculino, o que ocasiona menos probabilidade de mulheres cobrirem histórias ou serem personagens de reportagens; o mesmo relatório indica que o percentual de mulheres como fonte de informação ainda é baixo. 0 processo reproduz uma visão patriarcal persistente e é parte da chamada "invisibilidade" da mulher na mídia. Este trabalho pressupõe que também no Brasil, o processo de feminização das redações não é acompanhado de conteúdo que valorize a mulher, embora haja avanços. 0 texto apresenta cinco experiências brasileiras de jornalismo digital que buscam preencher a lacuna da cobertura tradicional sobre questões femininas, tratando a mulher como sujeito social autônomo. Examinou-se a estrutura destas iniciativas e analisou-se o conteúdo de cinco matérias de cada produto, nos meses de julho/agosto de 2016, para verificar como a mulher aparece como protagonista social. 0 trabalho permitiu refletir sobre um "novo jornalismo" que supere estereótipos, induzindo à visibilização e ao empoderamento social das mulheres. Conclui-se que as iniciativas analisadas podem ser consideradas pontos de observação para integrar práticas positivas no jornalismo hegemônico, ampliando o uso democrático e igualitário da mídia.
\end{abstract}

Palavras-chave:

Invisibilidade das mulheres; Jornalismo; Jornalismo online; Estereótipo de gênero; Mídias não hegemônicas

Abstract

Despite the feminization of journalistic newsrooms in Latin America, the Global Report on the Status of Women in the News Media (2015) indicates that the top

10 trabalho foi realizado com apoio de Bolsa de Pesquisa Capes. 
professional status in those places is still male, which leads to a lower likelihood of women writing stories, or being it's characters; the same report also demonstrates tha the percentage of women as a source of information is still low. The process reproduces the persistent patriarchal vision and is part of the so-called women «invisibility» in the media. This work assumes that also in Brazil, the feminization process of the editorial staff does not come along with any content that values the woman, although there are advances. The text presents five digital journalism experiments that seek to fill the gap of traditional coverage on women's issues, treating woman as an autonomous social actor. The structure of these initiatives was examined and their content, during the period July/August of 2016, have been analysed to verify how the woman appears as a social protagonist. This work allowed a reflection on how the «new journalism» can overcome stereotypes, inducing the visibility and the social empowerment of women. It is concluded that the analyzed initiatives can be considered points of observation to integrate positive practices in hegemonic journalism, expanding the democratic and egalitarian use of the media.

\section{KeYWORDS:}

Women invisibility; Journalism; Digital journalism; Gender stereotype; No hegemonic media

\section{INTRODUÇÃo}

Estudiosos sobre 0 tema (Castells, 2000; Casaca; 2012; Souza, 2014) concordam que mesmo com o avanço que integrou a mulher à esfera socioeconômica, especialmente no campo do trabalho, promovendo a feminização de alguns setores, persistem as lógicas de desigualdade, hierarquização profissional e permanência de estereótipos e preconceitos ligados ao gênero. No campo midiático e no subcampo jornalístico, esta lógica se confirma ao evidenciar uma representação simbólica assimétrica das mulheres nos mais diversos contextos. Ao analisar os dados do Global Report on the Status of Women in the News Media, de 2011, que avalia a participação das mulheres nos meios de comunicação, Juliana Souza (2014) conclui que 0 estatuto profissional mais elevado nas redações jornalísticas, inferido por sexo, é composto por homens, o que ocasiona consequências:

Isso concretiza-se na menor probabilidade de mulheres cobrirem histórias internacionais ou de serem pivôs. A feminização e a disparidade de género são derivados então, [...] de um processo em que os agentes intervenientes operam por meio de mecanismos patriarcais, que reproduzem a tipificação e a subvalorização do trabalho feminino. (Souza, 2014: 91).

Mesmo em países desenvolvidos como a França, a invisibilidade das mulheres na mídia é confirmada por diversos estudos, como a pesquisa GMMP (2015) que mostra que, naquele país, há uma regressão da representação das mulheres nos meios de comunicação: 24,1 \% em 2015, contra 28,3 \% em 2010; e que os homens formam $83 \%$ dos especialistas consultados pela imprensa, assim como constituem $83 \%$ das fontes citadas diretamente e $70 \%$ dos porta-vozes. Este quadro é parte 
do que chamamos de "invisibilidade da mulher na mídia" 2. Uma outra parte desta invisibilização, que poderíamos qualificar como borramento ou distorção sobre as mulheres, tal qual uma fotografia mal focada, relaciona-se à organização da própria narrativa jornalística. Como processo social de comunicação, que produz mediações, o jornalismo se inscreve como campo científico e técnico-profissional, como emissor de discursos com ethos próprio (Maingueneau, 2015). Tais discursos contêm representações do mundo e da realidade estabelecidos pelo "pensamento social" de seus colaboradores e podem gerar outras representações sociais ou referendar representações já cristalizadas em determinados grupos e segmentos da sociedade (Guimelli, 1993). Daí a identificação que surge, por exemplo, de um segmento conservador em seus valores políticos e culturais com relação àquelas mídias que representam suas ideologias e formas de pensar, reforçando-as e cristalizando-as. Por estas características, o discurso mediador do jornalismo,

[... ] interfere na construção e na difusão de referenciais de identidades e, particularmente, nas representações convencionais de género, e das posições-de-sujeito na sociedade (...) Tem-se como pressuposto amplo que as mídias atuam socialmente na (re)produção de valores, normas e símbolos, assim como na integração de papéis sociais e na formação de opiniões. (Souza, 2014: 92).

Embora não se desconheça que tal questão venha sendo estudada em diversos contextos geográficos e culturais (Nardelli e Sant'Anna, 2002; Silveirinha, 2004; Gill, 2007), este artigo se detém no panorama brasileiro, como recorte empírico; e parte do pressuposto de que no Brasil, que integra um panorama latino-americano mais amplo, o rápido processo de feminização das redações jornalísticas não vem acompanhado de um conteúdo noticioso que favoreça a valorização da mulher na mesma velocidade, embora haja avanços neste sentido. A partir daí, o texto tem como objetivo apresentar, por meio de uma pequena amostragem qualitativa, como alguns segmentos de jornalismo independente ou "não-hegemônico"3 ${ }^{3}$, no Brasil, buscam preencher uma lacuna em relação às questões femininas, passando a tratar a

2 A expressão "invisibilidade da mulher na mídia" é aqui utilizada no contexto do evento onde este artigo foi aceito e apresentado, nos dias 3 e 4 de novembro de 2016, denominado Journées d'étude "L'invisibilité des femmes dans les médias: Déconstruction des mécanismes d'exclusion", realizado no IJBA da Université Bordeaux Montaigne, em Bordeaux, França.

30 termo hegemônico é utilizado aqui no sentido específico do jornalismo, para tratar dos jornais tradicionais que dominam o mercado, mas deriva do sentido amplo empregado por Boaventura de Sousa Santos (2010). 0 autor atualiza o tradicional conceito de hegemonia de Gramsci e 0 traz para "0 cerne da discussão sobre as correntes teóricas da democracia no cenário global contemporâneo. Ao explicar estas teorias e as ações político-econômicas a elas acopladas, o estudioso as define como hegemônicas e contra hegemônicas. As primeiras, norteadas para a acumulação e apropriação capitalista com interesses ligados aos grupos dominantes, e as outras definidas pelas estratégias locais articuladas globalmente (glocal) em torno de experiências de solidariedade e uma busca por novas formas de emancipação social". (Machado et al, 2015, p. 10). Sousa Santos (2010) também faz uso do conceito da alternatividade, evidenciando que "para se dar voz às alternativas contradominantes, faz-se necessário um conhecimento que seja plural, edificado na comunhão das pequenas ações locais, ou micromovimentos" (Machado et al. 2015, p. 11), como um jornal independente, por exemplo, para nos aproximarmos do objeto de estudo deste trabalho. 
mulher em suas narrativas e notícias como sujeito social autônomo, com poder de decisão, interesses e opinião próprios, superando o modelo patriarcal ainda vigente. Daí surge a questão: em que medida essas novas iniciativas inseridas em sites na internet avançam em relação à pauta feminina apontada e criticada no jornalismo hegemônico? Além de outras questões mais específicas: Qual mulher é retratada nestes sites ${ }^{4}$ ? A quem se dirigem? Quem são as mulheres que produzem seu conteúdo?

Ao assumir que a invisibilidade das mulheres na mídia pode ser avaliada sob vários aspectos, estabelecemos a organização deste artigo em dois grandes tópicos: primeiramente, no exame da inserção das mulheres na prática do jornalismo profissional, com destaque para a feminização crescente das redações na América Latina, em especial no Brasil. Simultaneamente, são feitos alguns apontamentos sobre a baixa presença das mulheres no conteúdo das notícias, salientando-se dados coletados por meio de pesquisa bibliográfica sobre a temática na Internet e o relatório internacional já citado; emergem daí problemáticas relativas ao fazer da mulher jornalista, bem como a continuidade da reprodução de estereótipos patriarcais e de gênero.

Em um segundo momento, 0 trabalho apresenta a amostra de iniciativas de jornalismo não-hegemônico já citadas, selecionadas nas redes sociais, que indicam formas de buscar, em alguma medida, a superação das problemáticas e restrições de atuação, e estratégias de luta pela visibilidade da mulher. Neste contexto, considera-se a ampliação do sentido de jornalismo e do que se chama agora de "jornalismo alternativo" ou independente, no âmbito digital online.

Neste sentido, as iniciativas examinadas, em sua diversidade de textos e autoria, podem ser consideradas jornalísticas, embora nem sempre profissionais, pois de acordo com Ruellan e Adghirni (2009: 12), "o jornalismo é uma prática social de produção discursiva antes de ser uma profissão", que coloca "em interação três instâncias salientadas pela sociologia profissional: as fontes, as práticas, os públicos". Desta forma, os autores desconstroem concepções exclusivamente normativas do campo profissional, que considera como não jornalísticos discursos produzidos por não profissionais. Entretanto, há aspectos inerentes ao discurso jornalístico entendidos como "permanências" em um cenário de alterações aceleradas no campo, que são levadas em conta na análise dos produtos propostos.

As iniciativas examinadas nasceram na rede, por meio de projetos coletivos e não ligados a grandes grupos de mídia, políticos, organizações ou empresas sendo, portanto, consideradas independentes. Propõe-se uma análise genérica da estrutura de cada uma das experiências digitais e a análise de cinco matérias de cada iniciativa no período temporal considerado, verificando-se como a mulher aparece como protagonista social, a partir de algumas categorias pré-definidas, inferindo-se então a postura destes veículos. Busca-se a perspectiva qualitativa da análise de conteúdo, marcada pela interpretação controlada, que Bardin (2016) chama de "inferência", sem, no entanto, enfatizar de forma exaustiva a frequência de sua

4 Optamos pelo termo "sites" para identificar as iniciativas analisadas neste trabalho, embora alguns apresentem características de blogs ou revistas online. Entretanto, como não é o objeto deste texto discutir estas identificações de suportes digitais, optamos pelo termo "site" por ser mais abrangente e poder conter outros identificações. Lembramos ainda que no Brasil se usa amplamente o termo original em inglês, ao invés de "sítio", como se usa em Portugal. 
aparição de temas, personagens ou palavras inseridas em categorias específicas. 0 recorte temporal se estabelece entre os meses de julho e agosto de 2016, período possível com relação ao cronograma de elaboração do trabalho.

Em suma, de maneira ampla, o texto aponta o problema da ainda baixa visibilidade da mulher na mídia jornalística, mas também busca sugerir reflexão sobre estas formas digitais de um "novo jornalismo" que busca a superação de estereótipos, e que, mesmo à margem do padrão hegemônico de produzir notícias, está ligado a iniciativas conscientes sobre o papel da mulher na sociedade e, simultaneamente, demonstram como 0 jornalismo na internet pode ser indutor da visibilização das mulheres e de seu empoderamento.

\section{Mulheres nas redações e na narrativa jornalística: América Latina e Brasil}

0 número de mulheres na prática profissional do jornalismo e a forma como elas aparecem na produção jornalística são tópicos importantes nesta análise. Nos últimos dez anos, a América Latina avançou significativamente no primeiro destes dois pontos. De acordo com relatório de 2015 do Projeto de Monitoramento Global dos Meios (GMMP, em inglês), organizado pela Associação Mundial para a Comunicação Cristã (WACC, em inglês) ${ }^{5}$, em parceria com a ONU Mulheres, $41 \%$ dos jornalistas no continente eram mulheres (47\% dos repórteres da imprensa escrita, $36 \%$ dos jornalistas de rádio, e $50 \%$ dos jornalistas de televisão), um crescimento significativo se comparado ao percentual de $27 \%$ no ano 2000 . 0 relatório indicou que o percentual de mulheres na América Latina que atuou como fonte de informação para o noticiário ou foi objeto de notícias cresceu de 16\% em 1995 para 20\% em 2015. Os números ainda são baixos, mas já revelam aumento na visibilização feminina na mídia jornalística, no continente.

Por outro lado, ao se examinar as faixas etárias dos jornalistas no mesmo continente, 0 relatório indica que enquanto os homens são valorizados por sua experiência, as mulheres o são por sua juventude - $43 \%$ das mulheres jornalistas têm entre 19 e 34 anos, enquanto 14\% dos repórteres homens estão neste grupo e 53\% dos repórteres homens têm entre 35 e 49 anos, enquanto as mulheres são apenas 33\% nesta faixa. Tais dados parecem expressar o forte viés de patriarcalismo cultural da região, mas também remetem ao crescente número de mulheres que se graduam como jornalistas no ensino superior nas duas últimas décadas.

Mas, continua preocupante o fato de que, ao se analisarem as notícias por temas (na América Latina as mulheres foram o tema central das notícias em 17\% das matérias), as "mulheres são o personagem principal em 20\% das matérias de delinquência e violência" (Holt, 2015), contra 16\% em matérias sobre arte, esportes e celebridades e apenas $10 \%$ em matérias sobre os temas de política, governo e saúde. Holt destaca, ao comentar o relatório da WACC com relação aos dados latino-americanos, que "só em 6\% das histórias noticiadas tanto por homens quanto por mulheres jornalistas os temas têm a ver com igualdade de gênero; a maioria das notícias reforça os estereótipos de gênero", o que novamente revela o viés patriar-

5 A WACC realiza um projeto global de monitoramento da mídia, a cada cinco anos, sobre a representação de mulheres e homens na imprensa do mundo, considerado o maior estudo sobre gênero na mídia. 
calista que persiste na região, entendendo-se este conceito como a visão ideológica de supremacia do homem nas relações sociais, que permanece embutida nas representações midiáticas, em maior ou menor grau.

0 Brasil faz parte do quadro latino-americano de feminização progressiva das redações jornalísticas, com destaque para o crescimento, já há algumas décadas, de mais estudantes mulheres do que homens nos cursos superiores de jornalismo e nas redações das mídias tradicionais e das novas mídias digitais. Conforme Mick (2012: 1), "entre 1990 e 2010, o número de cursos universitários de jornalismo no Brasil foi quintuplicado", ocorrendo uma relativa democratização de acesso à educação superior no país. 0 quadro se refletiu no estudo de jornalismo que se expandiu por todo o país, contribuindo para alterar a configuração do campo, inclusive com relação ao sexo: "Por exemplo, os grupos de egressos, em sua maioria jovens e mulheres, podem ter estendido características similares de idade e sexo à totalidade da profissão" (Mick, 2010: 1).

0 jornalista Francisco Sant'Anna (2013) apontou que, de 1986 a 2004, a participação média dos jornalistas do sexo masculino foi de $58 \%$ dos empregos. Mas 0 mercado de trabalho experimentou um claro processo de feminização:

Se em 1986, pelos dados do Ministério do Trabalho, elas representavam $35,24 \%$ da categoria - ou seja, para, aproximadamente seis homens jornalistas existiam pouco mais de três mulheres (...) Em 2007, último dado que disponho, 0 gênero, demonstrando a crescente presença nas redações, já representava 53,49\%. (Sant'Anna, 2013).

0 pesquisador assinalou que as mídias eletrônicas, televisão e rádio, na época de sua pesquisa, eram aquelas que, ao longo dos anos, percentualmente, menos empregavam mulheres: "Apesar da visibilidade televisiva e da linha estética das redes de televisão brasileira, que priorizam a beleza e a juventude, 0 segmento ainda é um reduto masculino. No rádio e na TV as mulheres jornalistas apresentam, a partir de 2000, queda no espaço ocupado (Sant'Anna, 2013). Entretanto, a partir de 2004, o percentual se elevou para 39.23\% de representação de mulheres nestas mídias, atingindo 42.25\%, em 2007.

É fundamental relacionar o fato de que, como já colocado, há cada vez mais mulheres do que homens nas universidades brasileiras, mas ao buscarem um emprego no mercado elas ganham 30\% a menos do que os homens e raramente ocupam posições hierárquicas superiores. Para a pesquisadora e coordenadora da Rede Mulher, Vera Vieira, essa desigualdade provoca consequências que não aparecem nas estatísticas:

Não é uma questão de saber quem vai ficar com a maior fatia do bolo, mas de modificar a receita do bolo. Daí a importância da mídia estar atenta e desempenhar um papel na via contrária. Em vez de reforçar, combater preconceitos. Seu papel não é só de refletir a sociedade, mas é também educativo, central na construção de um outro mundo. Quando a Globo apresenta mulheres repórteres e âncoras que atendem ao chamado "padrão global", eu não me vejo retratada ali. A mulher negra se vê? A gorda, a idosa? (Vieira, apud Barbosa, 2006). 
A pesquisa de Sant'Anna (2013) ressaltou que o maior equilíbrio entre homens e mulheres estava na imprensa. E não é surpresa, pelo próprio perfil da área, que a maior presença das mulheres se estabeleça no segmento das assessorias de imprensa e nos setores de comunicação institucional (que emprega a maior parte dos jornalistas no Brasil): em 1986, elas representavam 38,96\% dos profissionais contratados por este segmento. Em 2004, já eram absoluta maioria: $58,42 \%$ e, em 2007, representavam 58,82\%. Nestas duas áreas há uma rotina que respeita, em geral, as leis trabalhistas, não há plantões em finais de semana e feriados, com horários cumpridos durante 0 dia, 0 que significa conforto para as mulheres que cumprem tarefas domésticas além da jornada profissional. Sant'Anna (2013) conclui que "a tendência de feminização do jornalismo brasileiro é fortemente impulsionada pelas estruturas de comunicação existentes fora das redações tradicionais".

A mais recente pesquisa encontrada durante a elaboração deste trabalho (Bergamo e Mick, 2012) revela que, em 2012, a feminização está instalada nas redações brasileiras profissionais: 64\% do universo é constituído por mulheres e 36\% por homens. Mas o quadro de inserção das mulheres jornalistas no campo profissional não representa as alterações necessárias com relação a representação da mulher no jornalismo hegemônico. Ele varia, inclusive, dependendo da área de cobertura. Um bom exemplo, é revelado pela pesquisa A mulher no noticiário brasileiro durante a Copa do Mundo 2014(Vieira e Duarte, 2014): a análise de 500 notícias de meios de comunicação de 26 estados brasileiros e do Distrito Federal, no dia 23 de junho de 2014 , revelou que apenas $23 \%$ das pessoas vistas, ouvidas ou a respeito de quem se lê nas notícias do período eram mulheres, em comparação a 77\% de homens ocupando o noticiário neste dia. Sob outra abordagem, ao realizar uma análise do estudo, a Agência Patrícia Galvão (2015) assinala que "as matérias apresentadas por repórteres femininas têm consideravelmente mais focos em temas femininos e questionam estereótipos de gênero quase duas vezes mais do que as produzidas por repórteres masculinos".

0 levantamento também constatou que o número de matérias produzidas por mulheres ainda é pequeno. 0 dado positivo da análise é que o percentual de matérias que reforçam estereótipos caiu de 48\%, no monitoramento da WACC em 2010 , para 9\% em 2014. Apesar do avanço nesse aspecto, de maneira geral, as mulheres ganharam destaque apenas em notícias sobre escândalos e violência. Além disso, o conteúdo analisado não destacava claramente assuntos relacionados à igualdade entre mulheres e homens (91\%). (2015).

Assim como apresenta crescente número de mulheres atuando no jornalismo profissional, há no Brasil um número significativo de publicações voltadas para mulheres, onde estas aparecem como fontes ou personagens das histórias, em especial no segmento de revistas. Mas, isto não quer dizer que as notícias e reportagens estabeleçam conteúdos que deixem de reforçar os estereótipos e preconceitos de gênero.

Conforme as coordenadoras da pesquisa acima citada, Vera Viera, da Rede MuIher de Educação, e Sandra Duarte de Souza, pesquisadora da Universidade Metodista de São Paulo, os estereótipos construídos culturalmente, e ao longo dos séculos, sobre as mulheres são reforçados pelos meios de comunicação jornalísticos: 
Parte-se do princípio de que os estereótipos nas diferentes mídias podem contribuir para reforçar as desigualdades. A construção assimétrica de gênero, raça-etnia e orientação sexual/identidade de gênero traz sérias consequências para toda a sociedade. A principal é a violência contra a mulher, que se materializa na vida cotidiana pela violência doméstica, violência sexual e tráfico de mulheres. Por outro lado, os mecanismos de intervenção podem fazer com que os veículos de comunicação se tornem instrumentos de transformação da realidade vigente (Vieira e Souza, 2014: 10).

As pesquisadoras ainda enfatizam o que vários outros estudiosos, como Tuchman (2009), para dar um exemplo, vêm apontando: ao apresentar notícias estereotipadas a mídia se configura como instrumento eficaz de imposição de uma estética prevalente para as mulheres, por meio da valorização de corpos jovens, esbeltos e majoritariamente brancos (Vieira e Souza, 2014). Mas, o estudo supera uma visão negativista ao concluir que os meios de comunicação alternativos, como aqueles que serão apresentados neste trabalho, podem contribuir para a divulgação de conteúdos críticos sobre questões de igualdade de gênero, pluralidade e diversidade, para que se possa "alterar a percepção e materialização assimétrica de poder entre as pessoas" (Vieira e Souza, 2014: 110).

Estabelecido este cenário, mais amplo, da desigualdade da mulher no interior das narrativas jornalísticas produzidas pelo jornalismo hegemônico brasileiro, que se torna paradoxal com relação à feminização das redações, registrada por várias pesquisas nos últimos anos, o texto avança no seu objetivo de apresentar e analisar as iniciativas de jornalismo digital "de mulheres, para mulheres e sobre mulheres", no contexto brasileiro, que podem se evidenciar como alternativas ao tratamento desigual e estereotipado das mulheres no jornalismo hegemônico, aspecto considerado como premissa deste trabalho.

\section{Visibilização da mulher na mídia alternativa online}

Não se pode deixar de reconhecer que "nas lutas pela emancipação da mulher, a mídia tem exercido uma função importante, prestando papel inconteste nessa trajetória (...) no cenário nacional ou internacional" (Vieira e Souza, 2014: 111). Uma visão crítica da comunicação, apostando em seu caráter emancipador, pode ser 0 caminho para a superação das assimetrias de gênero e dos conteúdos marcados pelos estereótipos patriarcais e sexistas. 0 relatório de pesquisa em tela aponta que "na era digital, as estratégias de comunicação mostram-se como um caminho para impulsionar a agenda feminista, balizadas por novas estratégias de intervenção política e de atuação, levando em conta outras dinâmicas e a revolução das formas de expressão pessoal e interpessoal" (2014: 110). Assim, as formas de representação da mulher podem ganhar outras dinâmicas, propiciadas por uma nova cultura comunicacional. Essa revolução se materializa nas formas de produção, interatividade - comunicação instantânea e processos colaborativos - compartilhamento e amigabilidade, criando novas relações de imaginários, o que permite promover ações de mudança de mentalidades (Vieira e Souza, 2014).

Em workshop para jovens film makers, realizado pela Unesco, em Beirute, no Líbano, em 2012, que discutiu também o acesso e controle às tecnologias digitais de comunicação, assinalou-se que, "há relações de poder desiguais em nossas so- 
ciedades que contribuem com as diferenças no acesso, na participação e no tratamento de homens e mulheres na tomada de decisão em todas as esferas da vida e em todos os níveis da sociedade." 6

As iniciativas de jornalismo digital a seguir apresentadas, nos parecem experiências interessantes na busca de uma visibilização midiática da mulher que vá além da feminização das redações tradicionais, pois temos como premissa que elas tentam, cada uma à sua maneira, mas respeitando princípios de jornalismo, estabelecer novas formas de representar a mulher como sujeito social autônomo, portador de direitos e responsável por sua trajetória de vida e participação político-social.

Iniciativas jornalísticas online para mulheres: "Quem somos"

As cinco experiências foram selecionadas a partir do apontamento da Agência de Reportagem e Jornalismo Investigativo Agência Pública (http://apublica.org/), que, em julho de 2016, indicou experiências de jornalismo independente online de diversas áreas. Evidentemente, nossa escolha recaiu sobre aquelas que tinham a mulher como público alvo.

AzMina (http://azmina.com.br/) é um site com conteúdo mensal sem fins lucrativos. Em 2015, a jornalista Nana Queiroz formou a Associação AzMina de Jornalismo Investigativo, Cultura e Empoderamento Feminino, com uma equipe que tem a diversidade como critério. 0 site quer contribuir para reduzir as desigualdades de gênero no Brasil, mudando a comunicação jornalística e publicitária no que se refere ao discurso de gênero e representatividade. 0 carro chefe é o jornalismo investigativo, "independente e de qualidade". As responsáveis garantem que trazem "temas usualmente esquecidos pela imprensa brasileira, como a falta de representatividade política da mulher e a violência doméstica" e que seus editoriais de moda "estão de acordo com princípios de sustentabilidade e rompem com o padrão de beleza inatingível, além de não usarem Photoshop".

0 site Cientista que virou Mãe (http://www.cientistaqueviroumae.com.br/) foi criado pela bióloga Lígia Senas para promover a reflexão crítica sobre a realidade das mulheres e da infância, apoiar o fortalecimento de mulheres mães e produzir informação à margem da mídia tradicional, "que é machista, desvaloriza mulheres e nos vende como produtos às grandes corporações". Constitui a primeira plataforma brasileira de informação produzida exclusivamente por mulheres mães — são jornalistas, cientistas e demais produtoras independentes de conteúdo, sem o patrocínio das grandes corporações. 0 modelo de negócio se baseia no financiamento coletivo dos textos produzidos pelas escritoras, com a vantagem de se poder escoIher o conteúdo de leitura, não se expor à publicidade, saindo do paradigma da exclusividade em direção à inclusividade, em uma visão colaborativa e responsável.

Nós, Mulheres da Periferia ((http://nosmulheresdaperiferia.com.br/) é um coletivo que propõe reduzir o espaço existente na imprensa e a falta de representatividade da mulher da periferia, 'buscando mais protagonismo e visibilidade, com a nossa própria voz". 0 grupo busca informações que extrapolem a questão de gênero a atinjam 0 campo social e étnico. São oito jornalistas, uma designer, moradoras de bairros da

6 http://www.unesco.org/new/pt/communication-and-information/crosscutting-priorities/gender-and-media/ 
periferia de São Paulo, que iniciaram a experiência desde 7 de março de 2012, quando quatro das mulheres jornalistas do atual coletivo publicaram artigo no jornal Folha de S. Paulo, atentando para a invisibilidade e os direitos não atendidos de mulheres que moram em bairros periféricos. Foi o ponto de partida para um processo de pesquisa e consolidação do projeto, que objetiva "dar visibilidade aos direitos não atendidos das mulheres, problematizar acerca dos preconceitos e estereótipos limitadores que se cruzam com as questões de classe social e raça e dar espaço para suas histórias".

Think Olga (http://thinkolga.com/): é um site de criação de conteúdo para refletir "a complexidade das mulheres", tratando-as "com a seriedade que pessoas capazes de definir os rumos do mundo merecem". Faz parte de um projeto feminista criado em abril de 2013 pela jornalista Juliana de Faria. Tem como missão "empoderar mulheres por meio da informação" e retratar suas ações "em locais onde suas vozes ainda são subalternas". Além disso, luta para as mulheres terem "mais escoIhas bem-feitas por meio da informação, sendo responsáveis por suas decisões".

Capitolina (http://www.revistacapitolina.com.br/) é um site independente para garotas adolescentes. Tem a intenção de representar todas as jovens, especialmente "as que se sentem excluídas pelos moldes tradicionais da adolescência", mostrando que elas têm espaço para crescerem da forma como são. Quer ser acessível e interessante "de forma inclusiva". Mistura diversas formas de arte e discussões sobre escola, relacionamentos, games, literatura, moda e culinária, "para que as garotas consigam se encontrar na revista, sentindo-se representadas". Os conteúdos são escritos e ilustrados por colaboradoras, incluindo quadrinhos, ensaios fotográficos e produção literária.

0 quadro abaixo apresenta outras características destas iniciativas jornalísticas online:

0 Quadro 1 apresenta características destas iniciativas jornalísticas online, em 2016

\begin{tabular}{|c|c|c|c|c|c|}
\hline $\begin{array}{l}\text { ITEM } \\
\text { ANALISADOS }\end{array}$ & AZMINA & $\begin{array}{l}\text { CIENTISTA OUE } \\
\text { VIROU MÃE }\end{array}$ & $\begin{array}{l}\text { NÓS MULHERES } \\
\text { DA PERIFERIA }\end{array}$ & THINK OLGA & $\begin{array}{l}\text { REVISTA } \\
\text { CAPITOLINA }\end{array}$ \\
\hline Ano de lançamento & 2014 & 2009 & 2012 & 2013 & 2014 \\
\hline $\begin{array}{l}\text { Público mensal do site } \\
\text { (Com informações de } \\
\text { press kit) }\end{array}$ & $150 \mathrm{mil} / \mathrm{mês}$ & $\begin{array}{l}\text { Sem } \\
\text { informação }\end{array}$ & $\begin{array}{l}\text { Sem } \\
\text { informação }\end{array}$ & $\begin{array}{l}\text { Sem } \\
\text { informação }\end{array}$ & $\begin{array}{l}\text { Sem } \\
\text { informação }\end{array}$ \\
\hline $\begin{array}{l}\text { Perfil do público } \\
\text { (Com informações de } \\
\text { press kit) }\end{array}$ & $\begin{array}{l}\text { Mulheres, de } \\
18 \text { a } 40 \text { anos }\end{array}$ & $\begin{array}{l}\text { Sem } \\
\text { informação }\end{array}$ & $\begin{array}{l}\text { Sem } \\
\text { informação }\end{array}$ & $\begin{array}{l}\text { Sem } \\
\text { informação }\end{array}$ & $\begin{array}{l}\text { Adolescentes } \\
\text { do sexo } \\
\text { feminino }\end{array}$ \\
\hline $\begin{array}{l}\text { Alcançe redes sociais } \\
\text { (Com informaçõ̃es de } \\
\text { press kit) }\end{array}$ & $\begin{array}{l}\text { Até } 2 \text { milhões/ } \\
\text { mês }\end{array}$ & $\begin{array}{l}\text { Sem } \\
\text { informação }\end{array}$ & $\begin{array}{l}\text { Sem } \\
\text { informação }\end{array}$ & $\begin{array}{l}\text { Sem } \\
\text { informação }\end{array}$ & $\begin{array}{l}\text { Sem } \\
\text { informação }\end{array}$ \\
\hline $\begin{array}{l}\text { Presente nas redes } \\
\text { sociais }\end{array}$ & SIM & SIM & SIM & SIM & SIM \\
\hline $\begin{array}{l}\text { Mulheres que compõe } \\
\text { a equipe }\end{array}$ & 21 & 34 & 9 & 1 & $\begin{array}{l}3 \text { Editoras } \\
20 \text { Coord. } \\
113 \text { Colabora- } \\
\text { doras }\end{array}$ \\
\hline $\begin{array}{l}\text { Homens que compõe } \\
\text { a equipe }\end{array}$ & 0 & 0 & 0 & 0 & 0 \\
\hline $\begin{array}{l}\text { Possui financiamento } \\
\text { coletivo? }\end{array}$ & SIM & SIM & NÃO & NÃO & NÃO \\
\hline
\end{tabular}




\begin{tabular}{|l|l|l|l|l|l|}
\hline $\begin{array}{l}\text { Há espaços de publi- } \\
\text { cidade? }\end{array}$ & SIM & NÃO & NÃO & SIM & SIM \\
\hline $\begin{array}{l}\text { Em caso de financia- } \\
\text { mento ou publicidade } \\
\text { divulga os dados? }\end{array}$ & SIM & NÃ̃O & N/A & NÃO & NÃO \\
\hline $\begin{array}{l}\text { Possui Loja Virtual? } \\
\text { com produtos à } \\
\text { venda para ajudar a } \\
\text { manter o veículo) }\end{array}$ & NÃO & SIM & NÃO & NÃO & NÃO \\
\hline
\end{tabular}

Quadro 1 - Características dos sites analisados em julho/agosto 2016 Fonte: os autores, com informações dos sites (2016)

Como sugere o título deste trabalho, estas experiências jornalísticas são espaços "de mulheres para mulheres". As cinco iniciativas foram criadas entre 2009 e 2014, com o objetivo comum de visibilizar questões femininas escamoteadas pelo jornalismo hegemônico, que apresenta cobertura considerada falha, superficial ou mesmo distorcida, reforçando estereótipos. Nenhum homem compõe as equipes dos sites, pelo que se verificou; a exceção é a autoria masculina de algumas ilustrações feitas por designers. 0 site Cientista que virou mãe é o único que possui espaço para publicidade externa e mantém uma loja virtual onde vendem produtos culturais, como livros, por exemplo. Apenas a Azmina divulga os dados de receitas e despesas com publicidade e financiamentos coletivos - os últimos dados disponíveis são de março de 2016. Na realidade, é esta a experiência que apresenta maiores detalhes informativos sobre si como produto editorial.

Mesmo tendo como prioridade as questões da mulher, as matérias produzidas são diversificadas, com enfoques e temáticas como direitos humanos, saúde, raça, educação, política, literatura. Todas as iniciativas estão presentes nas redes sociais.

Na sequência, são apresentados o processo de elaboração e as categorias de análise utilizadas neste trabalho. Buscou-se combinar categorias já utilizadas comumente no campo do jornalismo, como título e subtítulo, por exemplo, e nestas categorias introduzir "questões de operacionalização" que tocassem nos problemas de pesquisa, com o propósito de saber como estas iniciativas brasileiras se colocam como alternativa ao jornalismo hegemônico como, por exemplo, se as principais fontes consultadas eram femininas ou masculinas.

\section{Elaboração das CATEgorias}

Ao analisar, a título exploratório, duas matérias aleatórias de cada veículo, foi possível encontrar possibilidades de elaboração de categorias analíticas e de recortes para o corpus. Assim, percebeu-se que, mensalmente, a postagem das matérias era bem "assimétrica" - um site tinha 13 postagens, outro apenas duas, por exemplo. A partir daí, e ao se levar em conta a falta de simetria em relação à quantidade de postagens, para se obter um recorte satisfatório, estabelecemos a quantidade de 5 (cinco) matérias de cada veículo, sendo uma de destaque na página inicial e outras quatro aleatórias, totalizando 25 matérias. A partir do corpus definido, elaboramos sete (7) categorias analíticas que pudessem dialogar com a 
premissa e com o objetivo proposto. Segue a descrição destas categorias, acompanhadas de questões específicas para operacionalizá-las:

A - Título e subtítulo: 0 título, recurso editorial obrigatório, encabeça uma matéria para apresentar ao leitor o ponto principal da notícia. Deve ser concreto e relacionado ao tema, segundo Gradim (2000). Tem a função de ser chamativo, mas ao mesmo tempo, informativo, sintetizando a notícia. Já o subtítulo, pode ser utilizado ou não, colocando-se como uma frase também sintética abaixo do título, complementando-0, mas com informações extras. As duas categorias são aqui trabalhadas juntas. São questões de operacionalização desta categoria: A matéria possui um título e um subtítulo? Eles evidenciam mulheres? Há menção direta à mulher nesses recursos editoriais como, por exemplo: "Olimpíadas feministas"? 0 título/ subtítulo reforçam ou desafiam estereótipos de gêneros? Em que medida fazem isto, levando em conta que se tratam de mídias alternativas com estes propósitos.

B - Tipo da matéria: é o tipo de texto jornalístico empregado na matéria. Os tipos previstos são aqueles classificados por MELO (2003) e por vários manuais de redação jornalística, como próprios dos gêneros jornalísticos informativo e opinativo: Notícia: registro dos fatos sem opinião. Perfil: texto que retrata uma personagem específica, apresentando misto de informação e opinião. Reportagem: relato ampliado e aprofundado da notícia, que pode conter elementos interpretativos. Editorial/Comentário ou artigo de opinião: 0 editorial expressa a opinião do veículo; no jornalismo hegemônico não é assinado. Já o comentário (mais curto) ou artigo opinativo (mais longo) é menos formal que o editorial, pois não representa a opinião do veículo e é assinado. Entrevista: texto que leva ao leitor conhecimentos e opiniões sobre/dos personagens da matéria sobre determinados assuntos. Pode ser um texto corrido ou no formato de perguntas e respostas (ping-pong). Resenha: texto opinativo sobre produtos culturais contemporâneos: livros, filmes, exposições, peças, espetáculos etc. Crônica: texto em tom leve e pessoal, às vezes irônico ou literário, sem perder a ligação com a atualidade e o cotidiano, considerado um misto entre literatura e jornalismo. A operacionalização da categoria é feita a partir do enquadramento da matéria em cada tipo de texto jornalístico.

C - Autoria: Está relacionada a quem assina o texto como autor(a). É importante para analisar a presença feminina na elaboração das matérias. São questões de operacionalização desta categoria: A autoria do texto é feminina? Quem é a autora?

D - Temática e enfoque: É o tema central, o assunto principal, sobre qual a matéria está relacionada. Exemplos: olimpíadas, estupro, escola, dengue, eleições, cinema etc. Já o enfoque é o ponto de vista adotado pelo autor da matéria jornalística, a perspectiva escolhida para o leitor entender 0 assunto, a maneira do tema ser apresentado. Exemplos: político, educativo, econômico, ambiental, de gênero etc. A operacionalização da categoria é feita a partir do enquadramento da matéria em dada temática ou enfoque jornalístico.

E - Fontes: São as instâncias pessoais, institucionais ou documentais que os jornalistas consultam para obter informações/opiniões. Devem ser checadas e cruzadas com outras fontes para garantir confiabilidade informativa ao texto. As classificações consideradas são: Fontes femininas: mulheres como fontes de consulta das informações/opiniões. Fontes masculinas: homens como fontes de consulta das informações/opiniões. Fontes personagem: mulheres como fontes-personagem: 
como personagem central da matéria (nos casos de perfil e entrevista, por exemplo). Fontes institucionais: todas as que aparecem como não pessoais, mas que são citadas pelo nome de um órgão governamental, uma empresa privada, uma organização sem fins lucrativos ou um grupo social/sindical.

F - Recursos imagéticos: qualquer imagem que compõe a matéria. São questões de operacionalização: A matéria possui imagem? Fotos, ilustrações, gráficos ou outros recursos imagéticos? A imagem reforça ou desafia estereótipos de gênero? A imagem reproduz signos femininos estereotipados (como batom, vestido, salto alto, mulher cozinhando, valores tradicionais relativos à maternidade) ou desafia, problematizando estas relações?

G) Corpo da matéria: Compreende o conteúdo estabelecido do primeiro parágrafo até o fecho da matéria, levando-se em conta que não se trata de análise de discurso ou de conteúdo exaustiva, mas da busca de uma síntese interpretativa do conteúdo. Operacionalizam a categoria: $\mathbf{0}$ texto reforça ou desafia estereótipos de gênero?

Aplicamos estas categorias e as questões que as operacionalizam para chegar a inferências que permitiram a análise do material. Por economia de espaço, deixamos de apresentar as análises das 25 matérias analisadas, optando por uma síntese analítica do corpus como um todo?.

\section{ANÁLISE E discussões}

Segue-se uma síntese analítica de todas as matérias, organizadas pelas categorias definidas previamente.

1) Título e subtítulo: Todos os sites analisados utilizam títulos, mas apenas 0 Azmina utiliza também subtítulos — o layout elaborado para publicação online parece condicionar a não ocorrência de tal recurso. Todavia, estes sites utilizam outros mecanismos para chamar atenção do leitor: todos possuem chamadas: "resumos" nas páginas onde as matérias estão listadas. 0 Azmina utiliza o próprio subtítulo como resumo. Já os sites Nós, mulheres da periferia, Capitolina e Think Olga utilizam um excerto do primeiro parágrafo da própria matéria. Apenas Cientista que virou mãe utiliza uma chamada-resumo que parece ser criada especialmente para este campo. Em relação a segunda questão de operacionalização da categoria, apenas duas matérias do site Cientista que virou mãe não evidenciam diretamente as mulheres nos títulos: eles estão indiretamente ligados ao tema "maternidade", dado o contexto do próprio site, mas, lidos de forma isolada não evidenciam mulheres e sua relação com o conteúdo da matéria pode ser considerada fraca. Os títulos de todas as outras publicações evidenciam mulheres, ainda que por meio de palavras relacionadas ao seu universo. Sobre a terceira questão de operacionalização da categoria, os títulos de três das matérias analisadas, duas das mesmas que não evidenciam mulheres do Cientista que virou mãe e uma do Azmina, não desafiam estereótipos ou questões de gênero, se considerados isoladamente. Todos os outros títulos são desafiadores, pois reforçam a autonomia das mulheres na sociedade.

2) Tipo de matéria: A maioria das matérias analisadas, $32 \%$ (8) enquadra-se como artigo de opinião. Em segundo lugar, com 25\% (7), ficam as matérias

7 Os interessados podem obter as análises das 25 matérias selecionadas, solicitando-as pelo e-mail dos autores. 
do tipo reportagem. Assinale-se que mesmo nas matérias não classificadas como artigo de opinião, percebe-se a inserção de uma linguagem opinativa ou interpretativa sobre a situação reportada. É possível observar também que, somados, os tipos Entrevista e Perfil totalizam 20\% (5 matérias). Isto sugere que abordar casos reais de mulheres que sirvam de inspiração, por meio de personalidades reais (Lei Maria da Penha, coletivos feministas etc.) permitem a estes sites uma aproximação intimista do personagem com o leitor. Destacamos os maiores percentuais de tipos por site: Azmina, com 60\% (3) de reportagens; Capitolina, com $60 \%$ (3) da artigos de opinião; Cientista que virou mãe, com $80 \%$ (4) de artigos de opinião; Nós, mulheres de periferia e Think Olga, com 40\% (2) de reportagens. A maior diversidade nos tipos de matérias está nos sites Nós, mulheres de periferia e Think Olga.

Somados, artigos de opinião, entrevista e perfil, representam $52 \%$ das matérias. Assim, nesta categoria, o corpus que se coloca como alternativa ao que é apontado falho nos produtos informativos do jornalismo hegemônico, produz, no entanto matérias mais opinativas. Esta "contradição" sugere duas reflexões necessárias: a primeira, sobre uma nova configuração do jornalismo alternativo online pautado mais por produtos opinativos que informativos; depois, o quanto estas iniciativas alternativas realmente podem superar os pontos falhos do jornalismo hegemônico.

\begin{tabular}{|r|c|c|}
\hline ARTIGO DE OPINIÃO & 8 & $32 \%$ \\
\hline CRÔNICA & 2 & $8 \%$ \\
\hline ENTREVISTA & 3 & $12 \%$ \\
\hline NOTÍCIA & 2 & $8 \%$ \\
\hline PERFIL & 2 & $8 \%$ \\
\hline REPORTAGEM & 7 & $28 \%$ \\
\hline RESENHA & 1 & $4 \%$ \\
\cline { 2 - 3 } & 25 & \multicolumn{1}{|c|}{} \\
\cline { 2 - 3 } & &
\end{tabular}

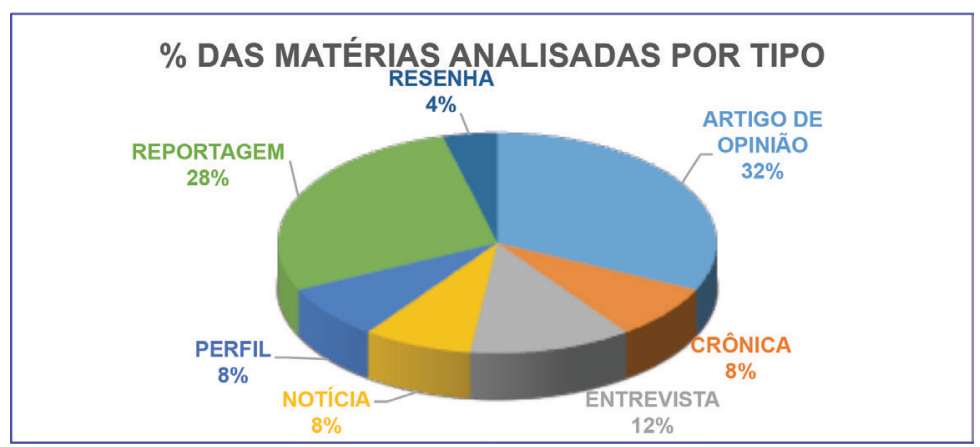

Figura 1 - \% das Matérias analisadas por tipo

3) Autoria: As autoras são todas mulheres (assim inferimos até mesmo nos casos das matérias assinadas pelos próprios sites, como no site Think Olga). No Azmina são quatro jornalistas e uma estudante de jornalismo e dentre as jorna- 
listas, destaca-se a qualificação acadêmica de duas delas (uma especialista e uma mestra). No Capitolina, apenas uma das autoras é jornalista, ou pelo menos assim se depreende (repórter de TV). Em outras duas matérias quem assina é uma estudante de jornalismo e ainda há espaço para profissionais de outras áreas (uma bióloga e uma ilustradora/estudante de design). No Cientista que virou mãe, uma autora, a criadora do site, bióloga e doutora, assina três das matérias. Nas outras duas, uma autora é jornalista e a outra, professora doutora de pós-graduação da UFRJ. É importante destacar que a Internet permite que outros profissionais, não jornalistas, possam transmitir informação jornalística, no que se chama de "jornalismo cidadão". No site Nós, mulheres da periferia duas das matérias são assinadas por jornalistas, sendo que uma delas assina duas matérias. A terceira é assinada pela Redação e a outra, por uma estudante de filosofia. No Think Olga, as matérias são assinadas pelo próprio site: apenas duas matérias trouxeram, ao final do texto, um perfil da autora, que se repete nestes dois casos. Assim, das 18 mulheres que assinam as matérias ("Redação", "Think Olga" e "Equipe", aqui consideradas como "autoras"), a metade é jornalista, conforme mostra 0 gráfico a seguir.

\begin{tabular}{|r|c|c|}
\hline JORNALISTA & 9 & $50,0 \%$ \\
\hline EQUIPE & 3 & $16,7 \%$ \\
\hline BIÓLOGA & 2 & $11,1 \%$ \\
\hline PROFESSORA DE PÓS & 1 & $5,6 \%$ \\
\hline ESTUDANTE DE JORNALISMO & 1 & $5,6 \%$ \\
\hline ESTUDANTE DE FILOSOFIA & 1 & $5,6 \%$ \\
\hline ESTUDANTE DE DESIGN & 1 & $5,6 \%$ \\
\cline { 2 - 3 } & 18 &
\end{tabular}

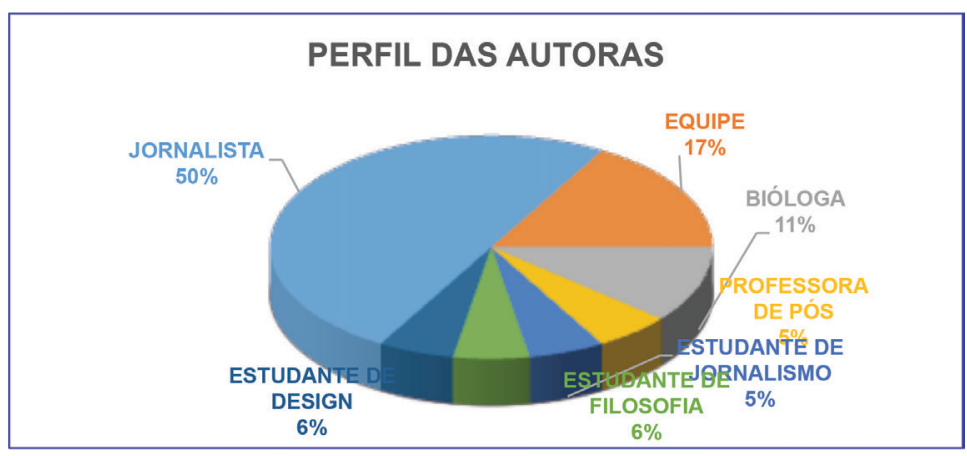

Figura 2 - Perfil das Autoras

No geral, os perfis das autoras ressaltam também informações pessoais como: "devoradora de livros, apreciadora de artes, adepta do ecletismo" e "considera a educação o mínimo múltiplo comum de todos os males do mundo". Assim, os perfis, inferimos, reforçam a figura autônoma destas mulheres em sociedade, ao dizer que: são jornalistas, biólogas, doutoras, professoras, estudantes, ilustradoras, mães, entre outras, que possuem seu ponto de vista sobre a socieda- 
de e sua relação com mulheres e, encontram nos sites espaço para visibilizar estes pontos de vista.

4) Temática e Enfoque: Dentre as temáticas que encontramos, "violência contra a mulher" lidera em 20\% (5 matérias). Este número é impulsionado pelo Caso Patrícia Lélis ${ }^{8}$ divulgado pelo Azmina e pelo Cientista que Virou Mãe, que aborda casos de violência obstétrica e cultura do estupro. Entre as temáticas depreendidas surge 0 "esporte" com 16\% (4) impulsionado pelo momento das Olimpíadas no Brasil e, depois, "Legislação" e "Negritude" ambas com 16\% (3, cada) - esta última temática, diretamente abordada apenas pelo site Nós, mulheres da periferia. As demais temáticas identificadas pontuaram menos de 8\%, são elas: "religião", "saúde e maternidade", "sexualidade", "autonomia", "infância", "educação e maternidade", "estética e auto estima" e "aborto". Sobre os enfoques empregados temos: com 32\% (8 matérias) tem enfoque "social-político", especialmente impulsionado pelo site Cientista que Virou Mãe que possui matérias longas com análises sociais aprofundadas. Em seguida aparece, com 28\% (7), 0 enfoque de "gênero". Com 12\% cada (3 matérias), temos os enfoques "político" e "psicológico-político". Evidente que um enfoque de gênero é, também, um enfoque político, especialmente nestes sites. Todavia, consideramos o foco principal para esta classificação. Os demais enfoques identificados pontuaram menos de 8\%, são eles: "jornalístico", "feminista", "racial".

5) Fontes: Dentre as 47 fontes identificadas, temos: mulheres, 62\%; institucionais, 30\%; e, masculinas, 9\%. Em três das matérias analisadas no site Revista Capitolina não foram utilizadas fontes. 0 mesmo aconteceu em uma das matérias do Cientista que Virou Mãe. Em uma das matérias da Azmina, uma fonte masculina recebeu mais destaque que a fonte feminina utilizada. 0 site que mais utilizou fontes femininas foi Nós, mulheres da periferia: um total de 14 fontes femininas, em especial em função de duas matérias que utilizam dez das 14 fontes, uma entrevista e um perfil. Na sequência, Azmina é o segundo site que mais utiliza fontes femininas, com nove no total. Os sites Capitolina e Cientista que Virou Mãe foram os que menos utilizaram fontes femininas - uma cada.

Ainda sobre o caso Patrícia Lélis, já citado anteriormente: o Azmina tentou falar com a fonte feminina principal, a vítima, mas ela se recusou. Considerando que 0 site conseguiu contato com um assessor do deputado acusado, uma fonte masculina, entendemos que houve um desequilíbrio entre fontes femininas (nenhuma) e masculinas nesta matéria. 0 caso serve para refletir sobre uma das críticas ao jornalismo hegemônico em casos semelhantes, que é o de justamente não ouvir a vítima nos casos das notícias de estupro - o AzMina reproduz aqui tal tratamento desigual. Neste caso, em que a vítima se negou a falar (algo to-

8 Trata-se da reportagem sobre o caso da jornalista Patrícia Lélis, que acusa o pastor e deputado federal Marco Feliciano de tentativa de estupro. As fontes são baseadas nas informações divulgadas pela mídia hegemônica, como o portal UOL: vídeos, áudios e os prints da conversa da jornalista com 0 deputado no celular. AzMina afirma ter tentado conversar com Lélis, que não aceitou. Outra fonte é Talma Bauer, assessor do deputado, acusado por Lélis de mantê-la em cárcere privado e de forçá- la a gravar vídeos inocentando o acusado. Consideramos tratar de reportagem que narra os fatos de forma muito semelhante às narrativas da mídia hegemônica. 
talmente compreensível), uma fonte feminina especializada sobre a questão da violência contra a mulher poderia ter sido consultada para equilibrar a questão do uso das fontes na matéria.

\begin{tabular}{|l|l|l|l|l|l|}
\cline { 2 - 6 } \multicolumn{1}{c|}{} & AZMINA & CAPITOLINA & $\begin{array}{l}\text { CIENTISTA QUE } \\
\text { VIROU MÃE }\end{array}$ & $\begin{array}{l}\text { NÓS, } \\
\text { MULHERES DA } \\
\text { PERIFERIA }\end{array}$ & THINK OLGA \\
\hline femininas & $69 \%$ & $20 \%$ & $10 \%$ & $94 \%$ & $67 \%$ \\
\hline masculinas & $12 \%$ & $0 \%$ & $20 \%$ & $0 \%$ & $0 \%$ \\
\hline $\begin{array}{l}\text { documentais/ } \\
\text { institucionais }\end{array}$ & $19 \%$ & $80 \%$ & $70 \%$ & $6 \%$ & $33 \%$ \\
\hline
\end{tabular}

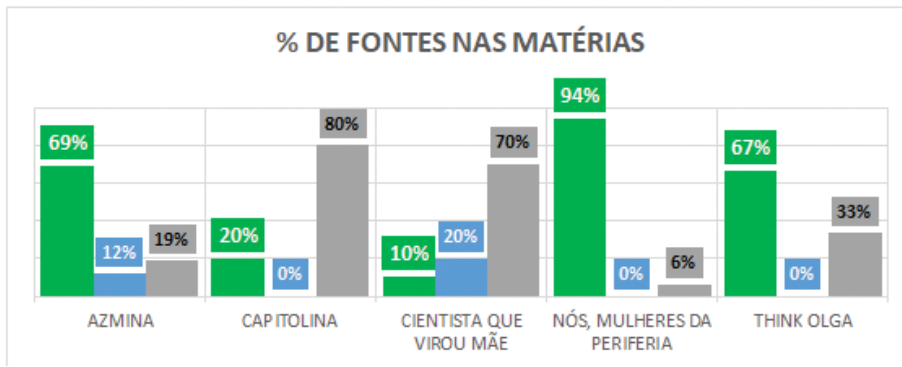

Figura 3 - \% Fontes nas Matérias

6) Imagens e recursos imagéticos: Todas as matérias utilizaram pelo menos uma imagem ou recurso multimídia imagético. Ao total, identificamos 55 recursos. Destes, $71 \%$ (39) são fotos (incluso foto como montagens), 16\% (9) são ilustrações, 7\% (4) são prints, 4\% (2) vídeos e 2\% (1) infográfico. Algumas das imagens se repetem no destaque da matéria e em seu corpo, como o caso da Think Olga. Sobre estas imagens desafiarem questões ou estereótipos de gêneros, consideramos inicialmente de modo isolado as imagens e, depois, recorremos ao conteúdo da matéria. Das 55, 69\% (38) desafiam questões ou estereótipos de gênero. Por site, os percentuais assim ficam: 27\% (3) no Azmina; 91\% (10) no Capitolina; 63\% (5) no site Cientista que virou mãe; 80\% (12) no Nós, mulheres da periferia e, 80\% (8) no Think Olga.

Analisados isoladamente, os sites possuem percentuais altos de imagens que desafiam os estereótipos ou questões de gênero. Em várias matérias elas adquirem tal força apenas ao considerá-las em diálogo com o corpo da matéria. As imagens assim, podem ter essa "dupla função": atrair os leitores para o assunto do texto e, após esta leitura, tornarem-se parte do texto, da mensagem, do tema, como é possível observar na figura abaixo: nela, a imagem de uma criança de salto alto e saia curta, num primeiro momento pode causar impacto pelo uso da imagem estereotipada em combinação com o título, no intuito de atrair o leitor, justamente em um site que se propõe a discutir tais questões. Ao mesmo tempo, em contato com 0 texto da matéria, a figura pode assumir outras significações, entre elas, a de problematizar o estupro infantil, a pedofilia e a responsabilidade da mídia nestas questões. 


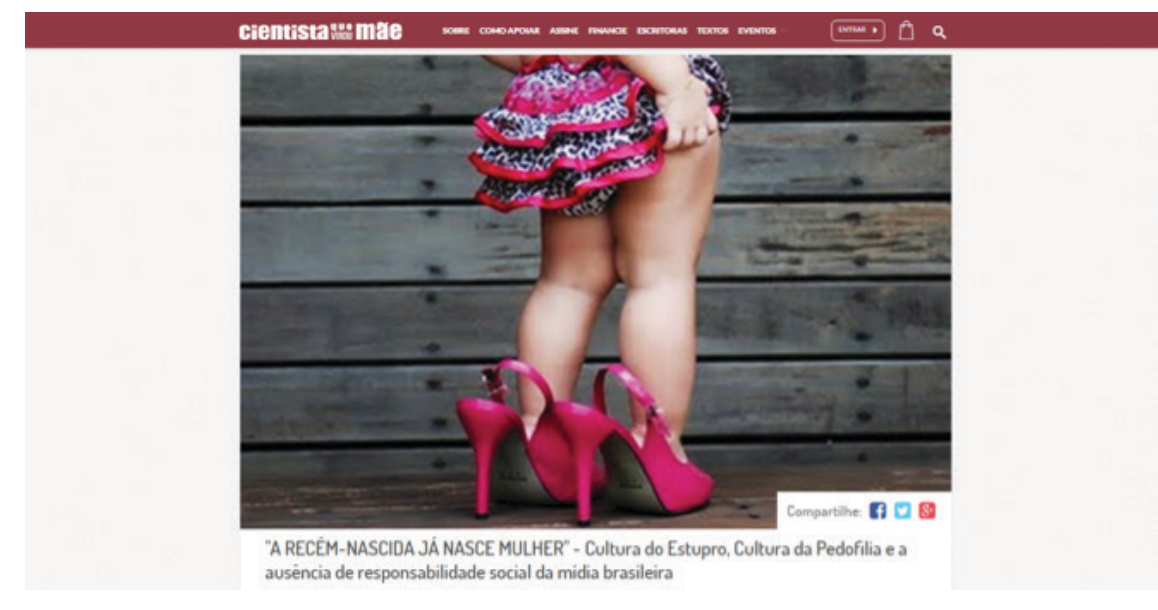

Figura 4 - Captura de tela com imagem com "dupla função" Fonte: site Cientista que virou Mãe (2017)

7) Corpo da matéria: Das 25 matérias analisadas, apenas quatro não desafiam nem reforçam estereótipos de gêneros. Entre os assuntos abordados estão: mulheres no esporte; a Lei Maria da Penha (que protege a mulher contra a violência doméstica), seus desafios e avanços; religiosidade e feminismo; maternidade; sexualidade lésbica; cultura; educação; violência obstétrica; mídia; empoderamento feminino; iniciativas de mulheres para mulheres; estupro e aborto. As problematizações sobre estes assuntos já são bastante pautadas por movimentos sociais como, por exemplo, de que "o esporte não é lugar de mulheres", da heterossexualidade compulsória, da cultura e educação que invisibiliza mulheres e/ou as trata como de segunda importância, entre outros.

Neste sentido, é importante lembrar que Joan Scott define gênero como uma conexão de duas proposições: "gênero como elemento constitutivo de relações sociais baseadas nas diferenças percebidas entre os sexos" e "uma forma primária de dar significado às relações de poder" (Scott, 1995: 86, grifo nosso). Assim, na primeira proposição Scott nos lembra da questão da "diferença percebida", isto é, o que se produz sobre gêneros (homem e mulher) enquanto categorias dualistas de diferença (percebida), faz o próprio gênero; e, na segunda proposição, que elas são uma forma primária de dar esse significado, isto é, é preciso ir além destas definições. Essa reflexão está perfeitamente relacionada ao que pudemos inferir destas matérias analisadas. É dizer que: se à mulher, na sociedade tradicional, é reservada a figura da passividade, da inabilidade para o esporte e para a política, por exemplo, é preciso compreender que esta é uma construção baseada nas "diferenças percebidas" entre homens e mulheres e, assim, deve-se buscar problematizar esta relação como uma "forma primária" em que o significado se cristalizou. Deve-se ainda considerar que esta problematização não pode cair na armadilha essencialista de produzir um sujeito feminino para contrastar ao masculino. Ao contrário: as matérias revelam um novo sujeito feminino, "empoderado", como se diz, mas único, fundado na ideia de identidade como essência, como já alertou Judith Butler (2015), 
que reconhece 0 caráter produtivo dos gêneros inclusive nas práticas que buscam desafiá-los enquanto categorias fixas e opressoras ${ }^{9}$.

Em algumas matérias analisadas, as autoras perderam a possibilidade de abordar ou aprofundar alguns temas, como questões relacionadas ao aborto e ao estupro. Um exemplo: no caso Patrícia Lélis optou-se por uma linguagem bastante imparcial, típica do "jornalismo hegemônico", estranha ao perfil observado nos sites. Neste caso, poderia ter sido abordada a questão do estupro em si. Nas matérias do Cientista que virou mãe, apesar do enfoque social e político aprofundado das matérias deste site, perde-se a oportunidade de trazer contribuições de fontes femininas, situação tão criticada no jornalismo hegemônico. Entretanto, em sua maioria, os textos são bastante críticos e aprofundados, mesmo que alguns deles não tenham explorado tanto as fontes femininas.

\section{Considerações finais}

Urge propor, organizar, incentivar e ampliar iniciativas de enfrentamento à opressão e às desigualdades históricas que se cristalizaram sobre as mulheres. Tal opressão estrutural, como já sublinhado aqui, se faz presente também no jornalismo hegemônico brasileiro que, apesar da forte presença feminina nas redações, constatada nas pesquisas destacadas na primeira parte deste artigo, ainda é criticado pela abordagem e tratamento machista de suas matérias. Assim, iniciativas como as dos sites jornalísticos aqui analisados constituem exemplos positivos de movimentos sociais que afirmam um papel ativo, livre, consciente e autônomo para a mulher em sociedade.

Para contraporem-se aos veículos hegemônicos, os sites analisados privilegiam mulheres autoras. A presença das mulheres também é preferida nas fontes, nas ilustrações e imagens utilizadas. Mas, principalmente (e este parece ser 0 potencial de enfrentamento destes sites para a questão da opressão), as mulheres também são presença nas pautas, nos temas, no enfoque. Como ressaltado no título deste trabalho, são iniciativas "de mulheres/para mulheres" e, por que não dizer, sobre mulheres - os tipos de matéria artigo de opinião, entrevista e perfil, juntos, somam $52 \%$ dos tipos de matéria, sugerindo isto. Também é possível inferir este viés de enfrentamento pelo alto índice de textos que desafiam estereótipos ou questões de gênero.

Isso, no entanto, nos leva a lançar uma nova questão: em que medida estas iniciativas contrastam efetivamente com relação aos veículos hegemônicos? Os tipos de matérias reportagem e notícia somam $36 \%$ e teriam um grande potencial de desafio aos estereótipos também; mas em reportagens como no caso de Patrícia Lélis, os fatos são abordados e reproduzidos da mesma forma que na mídia hegemônica. Inclusive o Azmina reconhece que "Vira e mexe o jornalismo nos bota em grandes dilemas éticos [...]". Esta questão é importante, pois se o que se busca é tornar 0 jornalismo hegemônico mais sensível à questão, é preciso que as iniciativas alternativas elaborem soluções que possam ser colocadas no campo dominante. Butler (2015) e Derrida (2013: 194), concordariam que "Não há fora-de-texto", isto é, uma

9 Não foi o objetivo deste trabalho investigar estes desvios, mas trata-se de interessante questão de pesquisa. 
ideia subversiva precisa partir da própria ordem que pretende subverter, inclusive porque nunca é pensada "de fora", mas sempre "de dentro" da lógica opressora.

Destaca-se positivamente a profundidade de enfoques no site Cientista que virou mãe. Todavia, o mesmo site foi pouco representativo no uso de fontes femininas. Os sites Azmina e Nós, mulheres da periferia destacam-se positivamente nesta questão das fontes e podem ser tomados como paradigmas pelo jornalismo hegemônico (e pelos próprios sites alternativos, claro).

Em suma, trata-se de um jornalismo de internet feito por mulheres, com conteúdos opinativos e informativos destinados a mulheres, sempre valorizando o papel da mulher na sociedade, sua forma de ser e estar, sua liberdade de expressão e, sobretudo, lutando contra os preconceitos e estereótipos culturais machistas/patriarcalistas que desvalorizam e ofendem todas as mulheres. Este tipo de jornalismo pode ser considerado uma alternatividade: Sousa Santos (2010) faz uso desse conceito, evidenciando que "para se dar voz às alternativas contradominantes, faz-se necessário um conhecimento que seja plural, edificado na comunhão das pequenas ações locais, ou micro movimentos" (Machado et al., 2015: 11). Nestas experiências, podemos afirmar existir a divulgação de um conhecimento cunhado por ações locais (Nós, mulheres da Periferia) ou por micro movimentos (perfis de mulheres como 0 de Maria da Penha, que levou à criação de uma lei que pune a violência doméstica causada pelo homem, publicada no site AzMina).

Iniciativas como as analisadas também podem ser consideradas pontos de atenção, nos quais é possível estabelecer observação para integrar práticas positivas no jornalismo hegemônico ampliando o uso democrático e igualitário da mídia. Evidente, é sempre necessário estar atento para quando (e se) as práticas partilham pressupostos fundacionistas, essencialistas e opressores (a ausência do tema da negritude - com exceções — nos sites é um exemplo), sob o risco de conformar toda subversão às normas opressoras (o alerta de Butler). É salutar estar aberto às possibilidades e esta é, sem dúvida, uma interessante questão de análise que lançamos aqui.

Se os dados apresentados pelos relatórios globais aqui apresentados (GMMP, 2011 e 2015) apontam para redações jornalísticas com um número majoritário de mulheres e vários dos autores citados (Vieira e Souza, 2014; Souza, 2014; Nardelli e Sant'Anna, 2002) apontam a ausência da mulher ou sua representação negativa nas narrativas jornalísticas hegemônicas, é importante não se deter nesta problemática contradição e seguir adiante. Assim, como defendemos na parte teórica do trabalho, em ressonância à Vieira e Souza (2014), ao se deixar de pensar a mídia de maneira maniqueísta, deve-se buscar realizar sua análise e a de seus produtos de maneira crítica e radical, entendendo-a também como um campo onde podem ser estabelecidos fluxos de informação e opinião, representados por discursos textuais e imagéticos, em múltiplas plataformas e com recursos multimídia, como os dos cinco sites aqui examinados, que potencializam a própria mídia como espaço de possibilidades de conquista e reafirmação de cidadania. Nesta conjuntura, Del Vecchio de Lima e Caetano (2015: 75) perguntam "sobre o que é ser jornalista hoje e o que é fazer jornalismo na cultura contemporânea, dentro do espírito da interatividade, da produção colaborativa e multiplicidade de vozes, produzindo e discutindo informação, visibilizada no próprio espaço midiático?" 
0 jornalismo digital online permite trilhar uma via de divulgação independente, análise, reafirmação e discussão da agenda feminista, garantindo novas formas de expressão pessoal e coletiva, que superam o profissionalismo rígido das redações, e podem interagir com iniciativas políticas e sociais. Ao final, trazemos uma frase de Jesús Martin-Barbero, muito bem lembrada por Vieira e Souza (2014: 93) - "há que se aproveitar as brechas". Este também é o pensamento de Edgar Morin e de Boaventura de Sousa Santos, autores que não se dedicam especialmente ao estudo das mídias e nem das questões femininas (embora elas estejam presentes em suas reflexões), mas que indicam como poucos, a necessidade da busca por novas alternatividades, brechas, contra-hegemonias, capazes de romper a sufocante realidade pautada pelo sistema dominante, nas mais diversas esferas, inclusive na cultural e de gênero. Se as possibilidades do jornalismo no âmbito das novas tecnologias são produtos capitalistas e hegemônicos, elas também são, sem dúvida, estradas repletas de brechas por onde se podem trilhar caminhos alternativos e independentes para divulgação de informação e opinião "de mulheres para mulheres" (e sobre mulheres).

\section{REFERÊnCIAS BIBLIOGRÁFICAS}

Agência Patrícia Galvão (2015). Monitoramento aponta invisibilidade das mulheres na cobertura da Copa do Mundo. In: (http://agenciapatriciagalvao.org.br/mulher-e-midia/ monitoramento-aponta-invisibilidade-das-mulheres-na-cobertura-durante-copa-mundo/) (Acesso: agosto 2016).

Barbosa, B. (2006). Em todo o mundo mulheres seguem invisiveis. In: (http://cartamaior. com.br/?/Editoria/Direitos-Humanos/Em-todo-o-mundo-mulheres-seguem-invisiveis-na-midia/5/9420) (Acesso: julho 2016).

Bardin, L. (2015). Análise de Conteúdo. Lisboa: Edições 70.

Bergamo, A.; Mick, J. et al. Quem é o jornalista brasileiro? Perfil da profissão no país (2012). In: (http://perfildojornalista.ufsc.br/files/2013/04/Perfil-do-jornalista-brasileiro-Sintese. pdf).(Acesso: novembro 2016).

Butler, J. (2015). Problemas de gênero: feminismo e subversão da identidade. Rio de Janeiro: Civilização Brasileira.

Casaca, S. (2012), Mercado de trabalho, flexibilidade e relações de género: tendências recentes. In: Mudanças Laborais e Relações de Género: Novos vetores de (des)igualdade, Lisboa: Almedina.

Castells, Manuel. 0 poder da identidade: A era da informação: economia, sociedade e cultura. v.2. São Paulo: Paz e Terra, 2000.

Del Vecchio de Lima, M. e Caetano, K. (2015). Implicações epistemológicas da pesquisa sobre novas práticas jornalísticas: por onde começar? Revista Famecos (Online) 22(3): 61-76. Derrida, J. (2013). Gramatologia. São Paulo: Perspectiva, 2013.

Gill, R. (2007), Gender and Media. Cambridge: Polity Press.

Global Media Monitoring Project (2015). In: (http://whomakesthenews.org/gmmp/gmmp-reports/gmmp-2015-reports) (Acesso: junho 2016).

Gradim, A. Manual de Jornalismo. In: (http://www.labcom-ifp.ubi.pt/ficheiros/20110826gradim_anabela_manual_jornalismo.pdf). (Acesso: maio 2016). 
Guimelli, C. (1999). La pensée sociale. Paris, PUF.

Holt, L. (2015) Proporción de mujeres em las salas de redaccióon de América Latina crece significativamente, disse estúdio. In: (https://knightcenter.utexas.edu/pt-br/users/lorenzo-holt) (Acesso: julho 2016).

Machado, C., Del Vecchio de Lima et al. (2015). Reflexões sobre a comunicação ambiental e o conceito de alternatividade em um cenário globalizado. Escritos-Revista de Ciências Humanas v. 11, n. 1, 9-20.

Mangueneau, D. (2015). A propósito do ethos. In: Motta, A.R. e Salgado, L.(ed.) Ethos discursivo. São Paulo: Editora Contexto.

Melo, J. M. de (2003). Jornalismo Opinativo. Campos do Jordão: Editora Mantiqueira.

Mick, J. (2012) A expansão do ensino de jornalismo no Brasil e a reconfiguração da categoria profissional (2000-2010). In: Congresso Internacional de Estudos sobre Periodismo 1., 2012, Santiago. Anais eletrônicos 2012a.

Nardelli, E. e Sant'Anna, F. (2002). Mulher e imprensa na América Latina. Brasília: Sindicato dos Jornalistas do Distrito Federal.

Ruellan, D. e Adghirni, Z. (2009). O Jornalismo como invenção permanente: novas práticas, novos atores. In: (http://www.intercom.org.br/papers/nacionais/2009/resumos/R4-15591.pdf). (Acesso: junho 2016).

Sant'Anna, F. (2013). Jornalismo, cada vez mais, uma profissão de mulheres. In: (http:// www.brasil247.com/pt/247/midiatech/95651/Jornalismo-cada-vez-mais-umaprofiss\%C3\%A30-das-mulheres.htm). (Acesso: junho, 2016).

Scott, J. W. (1995). Gênero: uma categoria útil de análise histórica. Revista Educação \& Realidade 20(2): 71-99.

Silveirinha, M. J. (2004), As Mulheres e os Media. Lisboa: Livros Horizonte.

Sousa Santos, B.; Meneses, M. P. (Eds). 2010. Epistemologias do Sul. São Paulo: Ed. Cortez. Souza, J. (2014). A invisibilidade das mulheres nos media: quando a representação de gênero define o sexo da notícia. Revista Media \& Jornalismo 24 (2): 91-103.

Tuchman, G. (2009). Media, Género, Nichos. Revista Media \& Jornalismo 15 (2): 15-24.

Vieira, V. e Souza, S. D. (2014). A mulher no noticiário brasileiro durante a Copa do Mundo 2014 (livro eletrônico). São Paulo: Rede Mulher de Educação.

Myrian Del Vecchio-Lima - Professora e investigadora do Departamento de comunicação da Universidade Federal do Paraná (UFPR). Bolseira Capes em estágio de pesquisa na Université Lyon Lumière2, Lyon (França).

Humberto da Cunha Alves de Souza - Publicitário, mestre em Comunicação pela Universidade Federal do Paraná. Doutorando em Tecnologia e Sociedade pela Universidade Tecnológica Federal do Paraná.

Data de recepção do artigo/ Received for publication: 03.01.2017

Data de aceitação do artigo/ Accepted in revised form: 07.03.2017 